\title{
RELASI TIMUR DAN BARAT DALAM PERMASALAHAN KONFLIK DI SURIAH
}

\section{Darmiko Suhendra}

Sekolah Tinggi Agama Islam Negeri Syaikh Abdurrahman Siddik darmikobangka74@gmail.com

\section{Abstract}

Based on historical fact, between Islam and the West theologically has strong bond which is on the meeting points and similarities between Islam and the West that inherit Jewish and Christian traditions. These three religions inherited the tradition of Prophet Ibrahim. However, theological similarities between Christianity and Islam precisely become the cause of collision between two of them. Historical problem between Islam and the West can be seen from the root of the conflict that includes: theological and political. Conflict between Islam and the West is covered by political motives. On the contrary, theology is only become justification to distinguish culturally and theologically between Islam and the West, basically this difference is more encouraged by political interest. Conflicts happen in Syiria is not because of religious factor, but it is more dominated by political and economic interest. The facts prove that most of Arab countries are the eternal alliance of the Western block, which was directed by The United States as the Solely Super Power in the world. Therefore, in the effort to build agreement and global coalition, actively promote cooperation. So that, the most important thing right now is the encounter between Islam and the West, that must be interpreted as building a dialogue of Civilization, not confrontation or mutual suspicion, building ideal relationship and also the need of harmonization between Islam and the West.

Keywords: West, Islam, Conflict 


\section{Abstrak}

Berdasarkan fakta sejarah, antara Islam dan Barat secara teologis mempunyai ikatan yang kuat yakni ada titik temu dan persamaan antara Islam dan Barat yang mewarisi tradisi Yahudi dan Kristen. Ketiga agama ini mewarisi tradisi Nabi Ibrahim. Namun, persamaan teologis yang ada antar Kristen dan Islam justru menjadi penyebab benturan di antara keduanya. Problem historis antara Islam dan Barat dapat dilihat dari akar konflik yang meliputi, teologis dan politis. Konflik antara Islam dan Barat tertutupi dengan motif politik. Sebaliknya, teologis hanya dijadikan justifikasi untuk membedakan secara kultural dan teologis antara Islam dan Barat, pada dasarnya perbedaan ini lebih didorong oleh kepentingan politik. Adalah konflik yang terjadi di Suriah bukanlah karena faktor agama namun lebih didominasi oleh faktor politik dan ekonomi. Fakta membuktikan, bahwa sebagian besar negara Arab adalah aliansi abadi blok Barat, yang dinakhodai langsung oleh Amerika Serikat sebagai kekuatan Super Power tunggal dunia. Oleh karena itu dalam upaya untuk membangun kesepakatan dan koalisi global, untuk secara aktif mempromosikan kerja sama. Oleh karena itu, yang terpenting saat ini perjumpaan Islam dan Barat harus dimaknai sebagai membangun dialog peradaban, bukan konfrontasi atau saling curiga, membangun hubungan yang ideal serta perlunya harmonisasi antara peradaban Islam dan Barat.

Kata Kunci: Barat, Islam, Konflik 


\section{A. PENDAHULUAN}

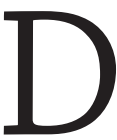
alam sejarahnya yakni kurang lebih selama empat belas abad, dunia Islam (sebagai representasi dunia Timur) memiliki sejarah yang panjang dalam pertemuannya dengan Barat. Pertemuan antara Islam dengan Barat yang telah berlangsung selama berabad-abad dan sampai sekarang masih berlangsung itu diwarnai dengan rivalitas, kerjasama dan juga konflik. Secara historis, peradaban Barat muncul lebih dahulu, baru kemudian disusul oleh munculnya Islam. Dan dalam perjalanan sejarah berikutnya, perkembangan Islam yang baru lahir lebih cepat, bahkan sampai dapat merontokkan Romawi dan Persi yang telah berjaya sebelumnya.

Setelah tujuh abad perkembangan Islam, Barat tidak mau kalah. Runtuhnya kerajaan Islam Spanyol merupakan momentum dimulainya babak rivalitas baru, yang kemudian disusul dengan era imperialisme-kolonialisme dunia Barat atas dunia Islam. Era imperialisme-kolonialisme ini berjalan hampir empat atau lima abad, dan ini merupakan simbol kemenangan Barat atas Islam sebagai komunitas sosial politik. Karena itulah, Rahman menyatakan sebagaimana dikutip oleh Hasbi bahwa bagi banyak pengamat, sejarah Islam di masa modern pada intinya adalah pengaruh Barat terhadap masyarakat Islam. ${ }^{1}$

Memang semenjak pecahnya Perang Dunia II menjelang paroh kedua abad ke-20, dunia Islam mulai melepaskan diri dari cengkeraman penjajahan Barat dan menjadi negara-negara merdeka. Akan tetapi, dalam banyak hal dunia Islam masih tergantung kepada Barat. Dana pembangunan, peralatan militer, tenaga konsultan dalam berbagai bidang, dan hasil industri berat, hampir semua negara Islam masih tergantung pada Barat. Ketergantungan dunia Islam pada khususnya dan dunia ketiga pada umumnya kepada Barat ini tidak lain adalah imperialismekolonialisme dalam bentuknya yang baru. Dengan kata lain dapat dinyatakan, meskipun dunia Islam telah melepaskan

1 M. Hasbi Amiruddin, Konsep Negara Islam menurut Fazlur Rahman (Yogyakarta: UII Press, 2000), h. 32 . 
diri dari imperialisme-kolonialisme Barat dan menjadi negaranegara merdeka sudah kurang lebih setengah abad, namun dalam kenyataannya dunia Islam masih berada dalam pengaruh dominasi Barat. Meskipun realitas sekarang menunjukkan, bahwa dunia Islam masih berada dalam pengaruh dominasi Barat, namun bukan berarti dunia Islam tidak punya kekuatan sama sekali. Oleh karena itu dalam makalah ini penulis akan mengkaji relasi atau hubungan dunia Islam (sebagai representasi Timur) dan Barat dalam puspa ragam permasalahan konflik di Suriah.

\section{B. PUSPA RAGAM RELASI TIMUR DAN BARAT}

Bahwasahnya beberapa orientalis berpendapat bahwa adanya dikotomi geografis bahwa dunia Barat adalah representasi dari Kristen sedangkan Islam merupakan representasi dari dunia Timur (memang pada awalnya yang diketahui oleh dunia Barat tentang dunia Timur hanyalah Islam. Saat ini Cina, Jepang, Korea dan India secara geografis adalah dunia Timur yang masuk kategori negara maju, namun populasi umat Islamnya tidak signifikan. Akan tetapi menurut Bryan S Turner bahwa memosisikan agama Islam dan Kristen dari sudut geografis dengan Kristen (juga Yahudi) sebagai agama Barat dan Islam sebagai agama Timur, sebenarnya menyimpan kerancuan. Hal ini karena Islam tidak sepenuhnya bersifat Timur, Kristen pun sebenarnyajuga tidak bisa dikategorikan sebagai agama Barat, karena sebagai kepercayaan Semitik yang berakar pada agama Abrahamik, dengan demikian Kristen dapat dipandang sebagai agama Timur. Sementara Islam yang menjadi bagian penting dari kebudayaan Spanyol, Sisilia dan Eropa Timur dapat dipandang sebagai agama Barat. Namun demikian memang dari sisi sosial, politik, ekonomi dan budaya kedua belahan bumi tersebut memiliki perbedaan yang sangat signifikan yang secara umum bertolak belakang. ${ }^{2}$

Pada abad-abad silam, Timur dan Barat memang pernah terlibat dalam berbagai gelanggang konflik politik dan arena

2 Bryan S. Turner, Runtuhnya Universalitas Sosiologi Barat Wacana atas; Islam vis a vis Barat, Orientalisme, Postmodernisme dan Globalisme, terj. Sirojuddin Arif, dkk, (Yogyakarta: Ar-Ruzz Media, 2008), h. 55. 
ajang pertarungan militer. Masing-masing pihak mempunyai kepentingan militer, politik, ekonomi dan sosial budaya yang saling berseberangan. Ekspansi-ekspansi teritorial dan penaklukkanpenaklukkan Islam atas Barat (dengan dikuasainya Andalusia atau Spanyol oleh umat Islam) pada abad ke-8 hingga abad ke-13 mencerminkan terjadinya arus gelombang benturan dan badai konflik-konflik yang sulit mencapai titik temu atau penyelesaian damai. Antara Timur dan Barat sering terjadi saling konfrontasi, saling adu kekuatan, dan saling tekuk untuk mengalahkan lawanlawan politik dan militernya di berbagai medan laga peperangan. Timur dan Barat terlibat dalam kemelut pertarungan politik dan militer yang berlumuran darah. ${ }^{3}$

Demikian juga arogansi dan supremasi Barat (dengan superioritas perlengkapan teknologi militernya yang sangat modern dan canggih) telah menyebabkan mereka melakukan eksploitasi, ekspansi dan penjajahan berabad-abad lamanya (dari abad ke-17 sampai pertengahan abad ke-20) atas dunia Timur dan negeri-negeri Muslim. Bangsa-bangsa Timur pun (termasuk Indonesia) bereaksi terhadap kekuatan-kekuatan kolonialismeimperialisme Barat dengan melakukan perang kemerdekaan untuk membebaskan negeri-negeri mereka dari penindasan-penindasan dan penjajahan Barat. Ini membuktikan bahwa antara Timur dan Barat pada abad-abad silam sering bertemu dalam arena konflik peperangan dan ajang pertarungan militer, dan tidak bertemu dalam forum-forum dialog dan kerjasama.

Seringkali yang terjadi relasi antara Islam dan Baratlebih banyak dikategorikan sebagai hubungan penuh benturan dan permusuhan. Barat yang oleh sebagian dunia Islam dipersepsikan sangat arogan, ambisius, sekuler, penjajah, eksploitatif dan anti Islam. Di sisi lain, Islam oleh Barat dipersepsikan sebagai agama penuh kekerasan, tidak menghargai hak asasi manusia, penghambat kemajuan, penebar teror dan agama sesat, telah menciptakan tatanan dunia penuh konflik yang berkepanjangan. ${ }^{4}$

3 Achmad Jainuri, Orientasi Ideologi Gerakan Islam: Konservatisme, Fundamentalisme, Sekularime, dan Modernisme (Surabaya: LPAM, 2004), h. 1.

4 Achmad Jainuri, Orientasi Ideologi Gerakan Islam: Konservatisme, Fundamentalisme, Sekularime, dan Modernisme, h. 3. 
Pertarungan, benturan dan konflik-konflik antar kekuatan dunia yang tercermin dalam perang dingin antara blok Barat (yang dimotori oleh Amerika) dan blok Timur (yang dikomandani oleh Uni Soviet) juga pernah terjadi di pentas percaturan dunia, dan ketegangan politik ini sangat mencemaskan masyarakat internasional. Kegamangan dan kecemasan masyarakat internasional yang sangat mendambakan perdamaian dan kedamaian semakin menjadi-jadi karena peralatan militer yang dimiliki baik oleh blok Barat dan blok Timur sangat modern dan canggih dan dapat memunahkan dan memusnahkan jiwa umat manusia dalam sekejap. ${ }^{5}$

Ketika perang dingin berakhir, Samuel P. Huntington, salah seorang pakar politik dan ahli kajian strategis Amerika Serikat, menjelaskan, bahwa benturan peradaban akan mewarnai dan mendominasi politik global. Menurutnya, identitas peradaban akan semakin penting pada masa akan datang dan dunia akan dibentuk dalam ukuran besar oleh interaksi di antara tujuh atau delapan peradaban utama: Barat, Konfuius, Jepang, Islam, Hindu, Slavia Ortodoks, Amerika Latin dan mungkin Afrika. Konflik yang paling penting pada masa akan datang terjadi di antara garis budaya yang memisahkan satu peradaban dengan yang lain. Beberapa negara yang lebih suka bergabung dengan Barat mengajukan westernisasi secara penuh, seperti Jepang, Rusia, negara lain di Eropa Timur dan Amerika Latin. Sementara yang tidak tergabung dengan Barat adalah, mereka menerima modernisasi tetapi menolak westernisasi. Huntington juga memperingatkan masyarakat Barat akan adanya ancaman baru terhadap Barat dan sekutu-sekutunya, yakni Islam. Peringatan ini diungkap secara jelas oleh Huntington dalam bukunya The Clash of Civillizations (benturan peradaban). Dalam bukunya itu ia mengatakan bahwa setelah ambruknya Uni Soviet, komunisme sekarang ini tidak lagi merupakan ancaman terhadap Barat. Menurut dia bahwa ancaman baru terhadap Barat adalah Islam (dan koalisi antara Islam dan Konfusianisme). ${ }^{6}$

5 Faisal Ismail, Ketegangan Kreatif Peradaban Islam; Idealisme versus Realisme (Jakarta: PT. Bakti Aksara Persada, 2003), h. 131.

6 Samuel P. Huntington, Benturan Antar Peradaban, dan Masa Depan Politik Dunia, terj. M. Sadat Ismail (Yogyakarta: Qalam, 2000), 43. Lihat juga Mohammade Arkoun, dkk. Serial Dialog Pencerahan Afkar; Orientalisme vis avis Oksidetalisme (Jakarta: Pustaka Firdaus, 2008), h. 118-119. 
Dalam hal ini perlu dikritisi analisis dan pendapat Huntington itu. Studi-studi strategis dan analisis-analisis kebijakan pada tingkat internasional yang dilakukan oleh Huntington telah membawa dia berpendapat bahwa Islam akan menjadi momok dan ancaman terhadap Barat. Pertanyaan kritis-dialektis yang perlu diajukan adalah bahwa Islam atau umat Islam mana yang merupakan momok dan ancaman terhadap Barat?. Apakah Islam atau umat Muslim di Arab Saudi dan Iran?. Atau Islam di Pakistan dan di Suriah?. Dan kita bisa melihat dan mengatakan secara pasti bahwa Islam di Arab Saudi sama sekali tidak merupakan momok dan ancaman terhadap Barat. Justeru Barat dalam hal ini Amerika Serikat selalu bermesramesraan dengan Arab Saudi karena Amerika Serikat mempunyai kepentingan ekonomi (pasokan minyak) dari Arab Saudi dan juga Arab Saudi sebagai lahan empuk pemasaran produk-produk Amerika Serikat (baca: konsumtif). ${ }^{7}$

Selajutnya al-Jabiri pernah mengatakan sebagaimana yang dikutip Donohue dan Esposito bahwa sebetulnya dua tahun sebelum Huntington, sudah ada tesis serupa yang dilontarkan oleh Buzan. Hanya karena tidak ditulis secara provokatif sehingga tidak populer gaungnya. Barry Buzan membuat sketsa ciri-ciri utama dari pola baru hubungan keamanan global yang timbul setelah transformasi besar tahun 1989-1990. Menurutnya, terdapat empat ciri dasar dari bentuk hubungan baru antara beberapa negara, yaitu: pertama, munculnya struktur kekuasaan multipolar di samping pusat bipolar yang telah ada sejak Perang Dingin; kedua, sebuah tingkat pembagian dan perselisihan ideologi yang lebih kecil; ketiga, kecenderungan dominasi internasional dari kelompok negara-negara kapitalis yang menaruh perhatian dengan masalah keamanan dan perubahan; keempat, sebuah konsolidasi dari kekuatan masyarakat sipil internasional. Perubahan-perubahan di pusat (negara-negara industri) akan memiliki akibat langsung maupun tidak langsung terhadap keamanan politik, militer, ekonomi dan sosial dari pinggiran (negara-negara non-industri). Akibat-akibat inilah yang disebut Buzan sebagai "benturan dari

7 Neal Robinson, Pengantar Islam Komprehensif, terj. Anam Sutopo, dkk, (Jakarta: PT. Bakti Aksara Persada, 2003), h. 6. 
identitas peradaban" yang berselisih, yang sangat mencolok antara Barat dan Islam. ${ }^{8}$

Dan mengenai relasi Timur dan Barat ini, Azyumardi Azra mengatakan bahwa dikotomi Timur dan Barat harus dipersempit. Sebab tidak semua hal yang dari Barat itu negatif, tetapi ada hal yang positif dan bisa membawa kemajuan bagi umat Islam. Azyumardi merasa optimistis, jika dikotomi antara Timur dan Barat ini dipersempit akan terjadi kedamaian. Bahkan umat Islam bisa hidup lebih maju karena orang Islam akan menggunakan sain dan teknologi tanpa melihat asalnya dari Barat atau negara mana. Selain itu, Azyumardi juga memperingatkan kepada umat Islam agar tidak boros dalam menggunakan sumberdaya. Selama ini ada kritikan jika orang Barat konsumtif. Namun umat Islam tidak kalah konsumtifnya, terutama negara-negara Arab kaya. Karena itu, Azyumardi menyarankan kepada negara Arab yang kaya agar tidak menghambur-hamburkan sumber daya mereka dan Sumber daya minyak atau apa yang telah dianugerahkan Allah SWT kepada kita menurutnya harus digunakan secara bijak dan cerdas, serta bisa meningkatkan kesejahteraan umat Islam. ${ }^{9}$

Dengan demikian, dalam upaya untuk membangun kesepakatan dan koalisi global, maka untuk secara aktif mempromosikan kerja sama. Oleh karena itu, yang terpenting saat ini perjumpaan Islam dan Barat harus dimaknai sebagai membangun dialog peradaban, bukan konfrontasi atau saling curiga, membangun hubungan yang ideal serta perlunya harmonisasi antara peradaban Islam dan Barat.

Hubungan historis yang panjang antara Islam dan Barat, dalam hal ini diwakili oleh Eropa, perlu ditinjau kembali sedemikian rupa, sehingga kedua belah pihak dapat mencerminkan dan memproyeksikan kerjasama baru dan bertanggung jawab, yang saling menguntungkan satu sama lain, terutama dengan penekanan untuk berbagi nilai-nilai sangat baik dalam peradaban masingmasing dan menemukan landasan bersama untuk membangun era jauh lebih baik dan sejahtera.

8 John J Donohue dan John L Esposito, Islam in Transition: Muslim Perspective (New York: Oxford University, 1982), h. 88.

9 https://www.republika.co.id/berita/pendidikan/dunia-kampus/14/03/17/n2k7ojzyumardi -dikotomi- barat- dan- timur- harus- dipersempit (diakses pada 1 November 2018). 
Agama -khususnya yang bersumber dari wahyu- menurut Azyumardi Azra, dalam kenyataannya lebih dari sebagai doktrin yang ada dalam kitab suci. Tetapi, agama wahyu hidup tidak hanya dalam kitab suci; dia juga menjadi realitas historis, sosiologis, antropologis, politis, dan sebagainya ketika dia dianut dan menyebar di lingkungan masyarakat manusia. Oleh karena itu, kitab suci agama wahyu sekalipun eksis tidak dalam lingkungan yang vakum dari realitas historis, sosial, budaya, politik, ekonomi, dan seterusnya. ${ }^{10}$

Dan Islam pada dasarnya membawa pesan perdamaian, universalisme, persaudaraan dan kesatuan umat manusia. Ini terkandung dalam ayat lā ikrāha fi ad-dìn, tidak ada paksaan dalam agama dan lakum dìnukum waliyadìn, bagimu agamamu bagiku agamaku. Namun itu bukanlah cerita keseluruhan. Tidak semua muslim memperhatikan al-Qur'an. Penyebaran Islam sering diiringi oleh kebencian, tekanan dan kekejaman. Khazanah penaklukkan Islam tetap membayangi kaum Muslimin di daerah yang mereka tidak lagi berkuasa. ${ }^{11}$ Sejarah dan masyarakat Muslim tidak bebas dari penyelewengan dan tirani. Hal itu adalah penyelewengan Muslim, bukan kualitas Islam.

\section{SEKILAS TENTANG SURIAH}

Timur Tengah merupakan wilayah yang sarat akan konflik yang seakan tidak pernah berhenti. Sumber daya alam yang dimiliki Timur Tengah terutama minyak menjadikan kawasan ini sebagai wilayah yang tidak pernah sepi dari konflik. Berbagai kepentingan negara-negara, baik yang termasuk dalam kawasan Timur Tengah maupun yang tidak termasuk dalam kawasan ini, saling berusaha mewujudkan kepentingannya masing-masing dengan berbagai cara. Karena kepentingan-kepentingan tersebutlah, stabilitas di Timur Tengah selalu menjadi sorotan dunia internasional.

10 https://republika.co.id/ berita/kolom/resonansi/18/08/09/ pd64jd440- agama- sebagairealitas-historis-1 (diakses pada 1 November 2018).

11 Akbar S. Ahmed, Membedah Islam, terj. Zulfahmi Andri, (Bandung: Penerbit Pustaka, 1997), h. 16. 
Adalah Suriah adalah sebuah negara yang terletak di Benua Asia, tepatnya di Asia Barat yang biasanya disebut dengan kawasan Timur Tengah. Dalam bahasa Inggris, nama Suriah identik dengan Levant, yang dikenal dalam bahasa Arab sebagai negeri Syam. Negeri ini, menjadi rebutan kekuasaan besar dunia sepanjang sejarah ummat manusia. Hal ini disebabkan karena letaknya yang sangat strategis, sebagai pintu gerbang antara negeri Barat dan Timur. Negara yang memiliki nama lengkap Republik Arab Suriah (Syrian Arab Republic) ini secara astronomisnya terletak di $32^{\circ}$ $38^{\circ} \mathrm{LU}$ dan $35^{\circ}-43^{\circ} \mathrm{BT}$. Secara geografis, Suriah berbatasan dengan Turki di sebelah utaranya, berbatasan dengan Yordanis di sebelah selatan dan berbatasan dengan Irak di sebelah timurnya. Sedangkan di sebelah barat Suriah adalah Laut Tengah. Ibukota Suriah adalah Damaskus. Luas wilayah Suriah adalah sebesar $185.180 \mathrm{~km} 2$. Bahasa resmi Suriah adalah bahasa Arab. Jumlah penduduk Suriah adalah 18.028.549 jiwa (estimasi Juli 2017). Terdiri dari 74\% Sunni, Alawi 12\%, Kristen 9\%, dan Druze 3\%. Jika dikombinasikan, maka 90\% dari populasi Suriah adalah Muslim. Sedangkan 9\% lainnya adalah Kristen, yang mencakup Kristen Arab, Assyria dan Armenia. Mayoritas populasi Suriah adalah etnis Arab (90\%) yang memeluk agama Islam, sedangkan minoritas terdiri dari etnis Kurdi, Asiria, Armenia dan Turkmens Circassians. ${ }^{12}$

Setelah Perang Dunia I, sebagian wilayah Suriah dikuasai oleh Perancis sebagai mandat atas runtuhnya Kesultanan Utsmaniyah (Ottoman Empire). Suriah memperoleh kemerdekaan sebagai negara Republik yang berdaulat pada tahun 1946. Tanggal 17 April 1946 yaitu tanggal dimana tentara Perancis meninggalkan Suriah ini diperingati sebagai Hari Kemerdekaan Suriah. Dalam sejarahnya, yaitu pada Februari 1958, Suriah bergabung dengan Mesir menjadi satu negara yang disebut dengan Republik Arab Bersatu (United Arab Republic). Namun penggabungan tersebut tidak berlangsung dengan lama, Suriah kemudian berpisah dengan Mesir menjadi Negara Republik Arab Suriah pada September 1961. ${ }^{13}$

12 Lihat https://www.kompasiana.com /coffeeaceh /550de202813311 b92cbc6013/mirismengapa-arab-ramai-ramai-memusuhi-suriah (diakses pada 4 November 2018).

13 Selama beberapa tahun Perserikatan Bangsa-Bangsa (PBB) meletakkan Suriah di bawah mandat Prancis sebelum akhirnya Prancis terpuruk pada 1940. Kendali atas Suriah pun segera 
Suriah merupakan negara yang menganut sistem pemerintahan Republik Presidensil. Namun Republik Presidensil Suriah ini memiliki jabatan Perdana Menteri sebagai kepala pemerintahan yang ditunjuk langsung oleh Presiden. Sistem pemerintahan ini juga berbeda dengan Republik Parlementer yang Perdana Menterinya merupakan pemimpin partai atau koalisi terbesar. Sedangkan Presiden Suriah dipilih langsung pada Pemilihan Presiden yang diselenggarakan setiap 7 tahun sekali. ${ }^{14}$

Hafez Al-Assad menjadi Presiden Suriah pada 22 Februari 1971, dan berkuasa sampai Juni 2000. Hafez Al-Assad telah mempersiapkan putranya yaitu: Basil Al-Assad untuk menggantikannya kelak sebagai presiden, tetapi Basil Al-Assad meninggal dalam kecelakaan mobil pada tahun 1994. Selanjutnya Bashar Al-Assad yang kala itu berada di London kemudian dipanggil ke Suriah untuk dipersiapkan menjadi presiden menggantikan kakaknya yaitu: Basil Al-Assad. Bashar Al-Assad lahir di Damaskus pada tanggal 11 September 1965. Dia adalah putra kedua dari mantan Presiden Suriah Hafez Al-Assad dan istrinya Anisa. Bashar Al-Assad dididik di Arab-French Al Hurriya School Damaskus untuk fasih berbahasa Inggris dan Prancis. Bashar Al-Assad lulus dari sekolah tinggi pada tahun 1982 dan melanjutkan studi kedokteran di Universitas Damaskus, lulus pada tahun 1988. Bashar AlAssad melakukan residensi di Tishreen Military Hospital luar kota Damaskus, dan kemudian berpindah ke Western Eye Hospital di London, Inggris pada tahun 1992. ${ }^{15}$

Latar belakang Bashar Al-Assad adalah seorang dokter spesialis mata bukan berlatar belakang dari politik maupun militer. Bashar Al-Assad resmi dilantik menjadi presiden Suriah pada 17 Juli

diambil Pemerintahan Vichy hingga Pemerintah Inggris dan Prancis kembali menjajah negara tersebut pada Juli 1941. Namun penjajahan ini sendiri tidak berlangsung lama karena kelompok nasionalis Suriah mendesak agar Prancis segera menarik keluar pasukannya dari Suriah pada April 1946. Suriah pun ditinggalkan Prancis dalam kendali pemerintahan republik yang telah lebih dulu terbentuk ketika Prancis memegang mandat PBB atas negara itu. Lihat http://pandri-16.blogspot. com /2015/08/mengenal-sejarah-terbentuknya-negara.html (diakses pada 30 Oktober 2018).

14 Lihat https://ilmupengetahuanumum.com/profil-negara-suriah-syria/ (diakses pada 30 Oktober 2018).

15 Lihat http://www.biography.com/people/bashar-as-assad-20878575 (diakses pada 1 November 2018). 
2000. Bashar Al-Assad dan keluarganya secara madzhab menganut Syiah, namun Syiah yang berbeda dengan Syiah Iran. Bashar AlAssad bukanlah pendukung dari konsep Wilayatul Fakih atau pemerintahan ulama di Iran. Bashar Al-Assad berpandangan hidup dan politik sekuler ala Barat. ${ }^{16}$

Ketika dilantik sebagai presiden, Bashar Al-Assad berjanji untuk menjadikan Suriah lebih modern dan demokratis. Dalam situs resminya, Bashar Al-Assad mengatakan akan membangun zona perdagangan bebas, mengizinkan lebih banyak koran swasta, dan juga universitas swasta serta memberantas korupsi dan pemborosan keuangan yang dilakukan pemerintah. Pada pertengahan 2001, Juru bicara pemerintahan dan Bashar AlAssad sendiri serta-merta menggambarkan kaum reformis sebagai agen Barat yang hanya bermaksud untuk menggerogoti stabilitas internal Suriah dari dalam, untuk kepentingan musuh-musuh negara. Pemerintahan yang berkuasa memerintahkan agar forumforum yang bermunculan di Suriah ditutup. Bahkan, sejumlah aktivis dari kubu reformis yang bersuara lantang mengkritik pemerintahan yang berkuasa untuk dipenjara. ${ }^{17}$

Rakyat Suriah tidak puas dengan kebijakan Bashar Al-Assad yang akhirnya melakukan demontrasi. The Arab Spring adalah titik puncak rasa tidak puas rakyat kepada pemerintahan. The Arab Spring merupakan gelombang demonstrasi besar-besaran dimulai dari Tunisia sampai ke negara-negara sekitar.

\section{PENYEBAB KONFLIK DI SURIAH}

Bahwasahnya The Arab Spring (kebangkitan Arab, secara harfiah berarti pemberontakan Arab) merupakan rangkaian protes yang berawal dari peristiwa di Tunisia, yakni peristiwa pembakaran diri yang dilakukan oleh Mohammed Bouazizi sebagai protes atas korupsi dan kesewenangan sikap Pemerintah Tunisia. Tindakan

16 http://m.voa-Islam-.com/news/Islamic-world /2011/ 10/ 24/ 16480 (diakses pada 1 November 2018).

17 Trias Kuncahyono, Musim Semi di Suriah: Anak-anak Penyulut Revolusi (Jakarta: Kompas, 2012), h. 72. 
Bouazizi melakukan protes membakar diri sendiri di depan gedung pemerintah di Sidi Bouzid, Tunisia telah melahirkan gerakan demonstrasi massal di seluruh Tunisia, dan kemudian menjadi inspirasi gerakan revolusi ke seluruh dunia Arab dan Afrika Utara. Bouazizi menjadi tulang punggung keluarga dalam mencari nafkah. Pemuda itu hanya berbekal sebuah gerobak, dan berjualan di sekitar kota Tunis, dan mendapatkan uang dari dagangannya sebesar sepuluh dolar (Tunis) per hari. Peristiwa yang membuat putus asa, ketika seorang aparat datang menghampirinya, kemudian menghancurkan gerobak berisi buah-buahan miliknya. Peristiwa itu berlangsung pada 17 Desember 2010, kabar kematian si penjual buah tersiar ke segala pelosok bumi dan pengguna media sosial, Twitter, terus berkicau membakar semangat perubahan dan menyuarakan hak-hak si tertindas. ${ }^{18}$

Protes di Tunisia kemudian menginspirasi gelombang kebangkitan yang menjalar ke Aljazair, Yordania, Mesir, Yaman, dan kemudian ke negara-negara lain. The Arab Spring juga melanda Suriah, sebuah negara yang relatif lebih stabil dibandingkan dengan negara-negara Arab lainnya, hal ini terjadi sejak 6 Maret 2011 gelombang demonstrasi prodemokrasi menyebar keseluruh penjuru Suriah terutama di kota Deraa, Suriah. ${ }^{19}$

Dalam perkembangannya pemerintah menggunakan kekuatan militer untuk menghadang aksi para demonstran yang membuat korban berjatuhan. Tindakan pemerintah yang dinilai melanggar hak asasi manusia ini membuat rakyat semakin tidak puas dengan kinerja pemerintah. Warga sipildan beberapa tentarayangmembelot dari pemerintahan berbondong-bondong bersatu dan membentuk unit pertempuran di bawah bendera Tentara Pembebasan Suriah (Free Syrian Army atau FSA) ${ }^{20}$ Carut marut konflik yang terjadi di 33.

18 M. Agastya ABM, Arab Spring: Badai Revolusi Timur Tengah (Jogjakarta: IRCiSoD, 2013), h.

19 Pada tanggal 6 Maret 2011 ini, lima belas anak sekolah berusia antara 10-15 tahun membuat coretan di dinding sekolah As Shaab Yoreed Eskaat el Nizam yang berarti "Rakyat Ingin Menumbangkan Pemerintahan", setelah terjadi penahanan terhadap kelima belas anak-anak kondisi Suriah segalanya berubah. Demontrasi semakin meluas. Lihat Trias Kuncahyono, Musim Semi di Suriah: Anak-anak Penyulut Revolusi, h. 114.

20 Amman (2012). Dua Ribu Tentara Syiria Membelot ke Jordania. m.jpnn.com/news. php?id=140870 (diakses pada tanggal 2 November 2018). 
Suriah menarik perhatian dunia internasional. Sejumlah negara dan organisasi-organisasi internasional turut serta dalam memberikan perhatian terkait konflik ini.

Ada beberapa faktor pemicu konflik Suriah, yakni:

1. Kesenjangan Ekonomi. Kesenjangan ekonomi yang dirasakan rakyat Suriah sejak masa pemeritahan Hafez al-Assad, terus berlanjut hingga anaknya, Bashar al-Assad, memimpin. Hal tersebut diperparah dengan kondisi rezim yang penuh dengan korupsi dan pegawai-pegawai pemerintahan yang haus akan suap. Pada masa pemerintahan Hafez al-Assad, perekonomian Suriah tertinggal jauh di bawah negara-negara disekitarnya diiringi dengan permasalahan-permasalahan seperti korupsi, kelebihan tenaga kerja yang tidak sesuai dengan jumlah lapangan kerja, inefisiensi atau tidak tepat guna dalam mengelola keuangan negara. Ketika Bashar al-Assad mulai berkuasa, ia mewarisi kondisi perekonomian dari ayahnya. Kondisi perekonomian pada saat itu memang tidak baik. Pada tanggal 16 Juni 2000 Jean Shaoul dan Chris Marsden menyebutkan perekonomian Suriah dalam masa kesulitan diantaranya, produksi minyak turun menjadi 400,000 barel per hari, Suriah kesulitan menjalankan pelayanan publik karena mengalami krisis, angka kelahiran tinggi dan pendapatan perkapita menurun. Suriah dari tahun ke tahun terus mengalami penurunan dalam bidang ekonomi. Ditambah dengan utang luar negeri yang terus membengkak. Produksi minyak per hari pada tahun 2010 tinggal 385.000 barrel, Padahal hasil ekspor minyak memberikan sumbangan sekitar seperempat dari pendapatan negara. ${ }^{21}$ Kondisi tersebut membuat perekonomian Suriah menjadi tidak stabil. Perubahan iklim yang ekstrim sepuluh tahun belakangan juga mengakibatkan Suriah dan negara Timur Tengah semakin kering. Hal tersebut tentu berpengaruh terhadap sektor pertanian Suriah. Karena semakin buruknya kondisi perekonomian, maka muncullah ketidakpuasan terhadap Pemerintahan mulai dari kelompok

21 Jean Shaoul and Chris Marsden. (2000). The Bitter legacy of Syria's Hafez Al-Assad. https:// www.wsws.org/en/articles/2000/06/assa-j16.html (diakses pada 2 November 2018). 
ekonomi yang terpinggirkan. ${ }^{22}$ Oleh karena itu perekonomian Suriah makin memburuk di tengah konflik yang sedang berlangsung sejak tahun 2011. Menurun lebih dari 70\% dari tahun 2010 hingga tahun 2017. Penurunan tersebut juga dikarenakan adanya dampak sanksi Internasional, kerusakan infrastruktur, berkurangnya produksi dan konsumsi dalam negeri, berkurangnya subsidi dan tingginya tingkat inflasi. Tingkat pengangguran Suriah juga sangat tinggi yaitu mencapai 50\%. Data terakhir yang dapat dikutip dari CIA world Factbook adalah data PDB dan pendapatan per kapita pada tahun 2015. Pendapatan Domestik Bruto atau PDB Suriah pada tahun 2015 adalah sebesar US $\$ 50,28$ miliar, sedangkan Pendapatan Perkapitanya adalah sebesar US\$2.900,-. Industriindustri penting bagi perekonomian Suriah diantaranya seperti Perminyakan, tekstil, pengolahan makanan, tembakau, semen dan perakitan otomotif. ${ }^{23}$

2. Kebijakan militer. Semasa masih berkuasa, Hafez Al-Assad merupakan tokoh yang pantas diperhitungkan dalam percaturan politik di Timur Tengah. Hafez Al-Assad sangat menentang hegemoni Amerika dan Eropa serta pendudukan Israel. Hafez Al-Assad selalu berjuang baik dalam medan pertempuran maupun di meja perundingan untuk memulihkan hak-hak bangsa Arab, menghadapi agresi dan pendudukan Israel, konspirasi serta propaganda yang dilakukan zionis. Sejak awal 1980an, Hafez Al-Assad mencanangkan kebijakan Suriah dalam konflik Arab-Israel yaitu kekuatan militer Suriah harus terus dibangun sampai mampu mengimbangi kekuatan militer Israel sekalipun tanpa bantuan dari negara-negara Arab lain. Pada tahun 1985, Hafez Al-Assad mengucurkan dana sebesar 3,5 milyar dolar AS atau 35\% dari anggaran belanja negara guna membangun sektor pertahanan. Itu belum termasuk pinjaman senilai 15 milyar dolar AS dari negara-negara Blok Soviet yang sebagian besar berbentuk bantuan alat-alat persenjataan.

22 Trias Kuncahyono, Musim Semi di Suriah: Anak-anak Penyulut Revolusi, 88.

23 Lihat https://ilmupengetahuanumum.com/profil-negara-suriah-syria/ (diakses pada 30 Oktober 2018). 
Setahun kemudian 1986, anggaran sektor pertahanan dinaikkan menjadi 56\% dari seluruh APBN. Pada tahun 1988 Hafez AlAssad juga membeli sejumlah peluru kendali jarak menengah dari RRC. Ada kesan bahwa pemerintah Suriah hanya ingin memajukan sektor militer saja karena anggaran belanja Suriah untuk mendanai kebutuhan pasukan militer sangat tinggi. ${ }^{24}$

3. Sunni-Syiah. Konflik Sunni-Syiah yang berkepanjangan turut mewarnai politik kawasan Timur Tengah. Konflik Suriah tidak terlepas dari campur tangan di balik layar antara Amerika Serikat dan sekutunya yang mayoritas negara Sunni, seperti Arab Saudi dan Turki melawan Rusia yang didukung Iran. Kedua pihak (Amerika dan Rusia) gencar mengirimkan bantuan berupa uang, alat persenjataan, pelatihan militer.

Selanjutnya tesis lain penyebab konflik di Suriah menyebutkan (dilansir dari situs independen Scoop) ${ }^{25}$ bahwa akar permulaan konflik Suriah yang sebenarnya, pada tahun 2011-2012 setelah Basyar al-Assad menolak proposal Turki untuk membangun pipa minyak dan gas alam antara Qatar dan Turki melalui Suriah, Turki beserta sekutunya menjadi 'arsitek utama dari konflik Suriah'. Proposal pipa gas itu jika diwujudkan maka akan memangkas pasokan gas dari Rusia ke Eropa yang selama ini didominasi oleh perusahaan gas Rusia Gazprom. Dengan kondisi itu Timur Tengah kian tercabik-cabik lantaran rencana pipa minyak dan gas yang kemudian dibenturkan dengan memperuncing perbedaan keyakinan atau agama. Situasi itu tentu dimanfaatkan oleh pihakpihak yang menginginkan pergantian rezim yang nantinya lebih bersedia membuka jalur pipa minyak dan gas kepada para penawar tertinggi yang berkepentingan. Pada 2012, Amerika, Inggris Prancis, Qatar dan Arab Saudi bersama Turki mulai membentuk, mempersenjatai, dan mengongkosi kaum pemberontak dari Pasukan Pembebasan Suriah (FSA), sesuai dengan rencana lama Amerika yang ingin memecah belah Suriah. Negara-negara itu kemudian sepakat untuk memecah belah Suriah lewat agama

24 M. Riza Sihbudi, Islam, Dunia Arab, Iran: Bara Timur Tengah (Mizan: Bandung, 1991), h. 116.

25 Lihat https://www.merdeka.com/dunia/kilas-balik-akar-penyebab-konflik-suriah-setelahlima-tahun.html (diakses pada 2 November 2018). 
sebagai jalan buat menggulingkan Presiden Assad. Dan di saat yang sama Suriah bersama Iran dan Irak justru membahas pembangunan jalur pipa migas yang rencananya akan dimulai antara 2014 dan 2016 dari ladang minyak Iran South Pars melalui Irak lalu ke Suriah. Jika itu terwujud, maka jalur pipa migas itu akan dengan mudah diperpanjang ke Libanon dan dengan demikian mencapai Eropa, sebagai target pasar.

Dengan demikian persoalan akses migas inilah dan bukan isu sektarian atau agama, yang menjadi akar penyebab konflik di Suriah. Namun yang lebih terlihat di panggung internasional, konflik ini adalah perseteruan Sunni-Syiah. Mengapa? Karena jika seluruh dunia tahu, orang-orang tidak akan mendukung kaum pemberontak seperti yang dilakukan Amerika, Saudi, dan koalisinya selama ini. Berbagai media asal Amerika dan Eropa membanjiri dunia dengan pemberitaan soal kekerasan dan penderitaan rakyat Suriah serta para pengungsi di Eropa dan konflik agama, namun berita-berita itu tidak menyoroti akar konflik yang sebenarnya yaitu kepentingan ekonomi dan politik.

\section{E. KEKUATAN DIBALIK KONFLIK DI SURIAH}

Konflik Suriah dimulai ketika kerusuhan menyebar, tindakan keras semakin meningkat. Para pendukung oposisi mengangkat senjata, pertama untuk membela diri dan kemudian mengusir pasukan keamanan dari daerah mereka. Lalu Assad berjanji untuk menghancurkan "terorisme yang didukung pihak asing" dan memulihkan kontrol atas negara. Kekerasan meningkat dengan cepat dan negara tersebut terjerumus ke dalam perang saudara, sekaligus menjadi awal mula perang Suriah karena ratusan brigade pemberontak dibentuk untuk melawan pasukan pemerintah. Intinya, perang Suriah ini menjadi lebih dari sekedar pertempuran antara mereka yang melawan Assad, namun telah menjadi intervensi kekuatan regional dan dunia, termasuk Rusia, Iran, Amerika Serikat dan Arab Saudi. Perang Suriah terjadi dengan adanya dukungan militer, finansial dan politik mereka untuk pemerintah 
dan oposisi telah memberi kontribusi pada intensifikasi dan kelanjutan perang Suriah tersebut dan menjadikan Suriah sebagai medan pertempuran proxy.

Ada beberapa kekuatan negara asing yang terlibat dalam konflik Suriah, baik yang mendukung ataupun yang menentang pemerintahan Bashar Al-Assad. Kekuatan-kekuatan itu adalah:

1. Rusia, yang menganggap kelangsungan hidup Presiden Assad penting untuk mempertahankan kepentingannya di Suriah, meluncurkan serangan udara pada bulan September 2015 dengan tujuan untuk "menstabilkan" pemerintah. Moskow menekankan bahwa serangan itu hanya akan menargetkan "teroris," namun para aktivis mengatakan bahwa serangan tersebut berulang kali menyerang kelompok pemberontak dan wilayah sipil yang didukung Barat. Intervensi tersebut telah mengubah gelombang perang yang menguntungkan Assad. Serangan udara dan rudal Rusia yang intens sangat menentukan dalam pertempuran untuk daerah Aleppo yang dikuasai pemberontak pada akhir 2015, sementara pasukan khusus Rusia dan tentara bayaran membantu memecah pengepungan ISIS yang telah berlangsung lama dari Deir al-Zour pada bulan September 2016. Dua bulan kemudian, Presiden Vladimir Putin memerintahkan sebagian penarikan pasukan Rusia, namun mereka terus melakukan serangan udara ke seluruh negeri. Dalam hal ini Rusia memiliki kepentingan geostrategis di kawasan. Suriah kini merupakan benteng terakhir Rusia, setelah Libya tumbang. Di Suriah, Rusia memiliki pangkalan angkatan laut di Tartus, bahkan sejak masa Uni Soviet, dan semakin membesar dalam tahun-tahun belakangan ini. Rusia juga punya pangkalan udara di Hmeimim, Latakia. Jadi, dalam tingkatan geostrategis, seandainya kehilangan Suriah, maka Rusia tidak punya keberadaan dan pengaruh diplomatis di Mediterania. ${ }^{26}$

2. Iran. Sementara itu, Iran pasang badan tak lain karena rezim

26 Suarapembaharuan.com. (2016). Rusia Tak Mau Suriah Hancur Seperti Libia. http:// sp.beritasatu.com/home/rusia-tak-mau-suriah-hancur-seperti-libia/14241 (diakses pada 2 November 2018). 
Suriah merupakan sekutu lama bahkan sejak perang Iran versus Irak meletus (Perang Teluk I 1980-1988), sebuah peperangan yang membawa kehancuran besar bagi kedua bangsa. Pada saat negara-negara Arab seperti Yordania, Oman, Arab Saudi memihak Saddam Hussein, Presiden Suriah Hafeez al-Assad (Ayah Bashar) menutup pipa minyak Irak dari Suriah ke Mediterania demi mendukung Iran, sehingga mengakibatkan Irak menderita kerugian besar. Sejarah juga mencatat, Suriah merupakan negara pertama yang mengakui kemenangan Revolusi Islam Iran pada tahun 1979 yang dibesut Ayatullah Khomeini. Teheran juga memiliki kepentingan dalam menjaga zona pengaruh dari Irak ke Suriah ke Libanon.Teheran masuk secara militer di pihak rezim Suriah sedari awal, yang disusul milisi Hizbullah Lebanon secara diam-diam pada tahun 2012. Tahun 2013 Hassan Nasrallah, pimpinan Hizbullah, menyatakan mereka mengintervensi di Suriah untuk melindungi tempattempat suci Muslim Syiah melawan kaum takfiri. Kekuatan Syi'ah Iran diyakini menghabiskan miliaran dolar setahun untuk mendukung pemerintah yang didominasi Alawi, memberikan penasihat militer dan senjata bersubsidi, serta jalur transfer kredit dan minyak. Hal ini juga dilaporkan secara luas telah menempatkan ratusan pasukan tempur di Suriah. Assad adalah sekutu Arab terdekat Iran, dan Suriah adalah titik transit utama untuk pengiriman senjata Iran ke gerakan Islam Syi'ah asal Lebanon, yakni Hizbullah, yang telah mengirim ribuan pejuang untuk mendukung pasukan pemerintah. Israel sangat prihatin dengan akuisisi persenjataan canggih Hizbullah dan apa yang mereka sebut sebagai "dorongan" Iran di Suriah bahwa pihaknya telah melakukan puluhan serangan udara yang berusaha menggagalkan mereka. Israel kerap memperingatkan tidak akan menerima kehadiran militer Iran secara permanen di Suriah. Israel khawatir bahwa ketika perang sipil di Suriah mulai berakhir, Iran dan puluhan ribu milisi Syiah akan mengalihkan fokus mereka ke Israel. ${ }^{27}$ Suriah dibawah kepemimpinan Bashar 
Al-Assad memberikan koneksi langsung kepada Iran untuk akses pengiriman senjata, tentara dan dana kepada hamas dan hizbullah yang merupakan kelompok anti Israel. Dan salah satu alasan Iran mendukung Bashar adalah untuk mempertahankan mitra dan sekutu dalam pengembangan senjata pemusnah masal untuk menjamin keamanan bersama dan pengaruh regional. Hubungan Iran dan rezim Bashar yang sama-sama Syiah juga menjadi salah satu alasan Iran untuk mendukung Bashar. Akan tetapi kesamaan ideologi Syiah ini bukan menjadi alasan utama Iran mendukung Bashar, melainkan dipandang sebagai cara untuk mendapatkan tujuan dan kepentingan Iran di Suriah. Adanya kesamaan ideologi Syiah mempermudah Iran untuk mendapatkan dukungan dan kerjasama dari rezim Bashar. Alasan kesamaan ideologi dan identitas Syiah antara Iran dan rezim Bashar al-Assad lah yang menjadi alasan Iran mendukung Bashar dalam konflik Suriah. Iran juga melihat bahwa kejatuhan Bashar akan mengancam keberlangsungan penguasaan Syiah di Suriah. Apabila Basar jatuh, maka kelompok oposisi lah yang akan menggantikan Bashar dan kelompok oposisi tersebut berasal dari kaum Sunni. Kepemimpinan Sunni di Suriah, dianggap sebagai ancaman untuk keberlangsungan penyebaran Syiah di Suriah. Norma yang dimiliki Iran sebagai negara Islam Syiah memberikan Iran tanggung jawab moral untuk menjadi pelindung sekaligus pemimpin bagi dunia Islam. Mohammad Javad Larijadi, teoritisi hubungan internasional pertama Republik Islam, kemudian melahirkan konsep the Mother of the Cities (omm al-qorã') of the Abode of Islam. Ekspor revolusi ke seluruh dunia Muslim adalah tugas inheren bagi Iran sebagai titik episentrum persatuan ummah. Iran juga diwajibkan untuk melindungi keselamatan kaum Muslim, dalam hal ini tentu saja muslim Syiah, sehingga menjadi keharusan bagi Iran untuk mendukung pemerintahan Bashar dalam konflik Suriah.

3. Amerika Serikat. Setidaknya ada dua alasan keterlibatan yang dilakukan Amerika Serikat terhadap konflik Suriah. (a) kepentingan ekonomi. Dalam kepentingan ekonomi, sudah dari dulu bahwa Amerika Serikat selalu fokus terhadap 
pemenuhan energi untuk kebutuhan dalam negerinya, hal ini terutama tergambar dalam kepentingan Amerika Serikat terhadap minyak Timur Tengah yang tampak pada dokumen tahun 1944. Departemen Luar Negeri AS menggambarkan semenanjung Arabia sebagai sumber besar bagi kekuasaan strategis dan hadiah material terbesar dalam sejarah dunia. Tuntutan akan tersedianya pasokan energi dalam negeri serta keberlangsungan negara sekutu menjadi dasar tindakan Amerika Serikat mengenai konflik Suriah, segala cara tentu akan ditempuh dikarenakan kebutuhan akan energi merupakan kepentingan ekonomi penting bagi Amerika Serikat. Tidak menguasai pengendalian cadangan energi minyak maupun gas akan meretas jalan menuju kehancuran bagi ekonomi Amerika Serikat yang digerakkan secara aktif melalui perindustrian. Dan (b) dalam kepentingan politik. Dengan keberhasilan menggulingkan pemerintahan Bashar Al-Assad, Amerika Serikat semakin terbuka peluangnya untuk memperluas pengaruh politiknya di kawasan Timur Tengah secara penuh. Amerika Serikat membuat penawaran terhadap pemerintahan Suriah, yaitu Suriah harus membekukan hubungan dan menutup kantor-kantor faksi oposisi Palestina di Damaskus dan menghentikan bantuan politik, dana serta senjata pada Hizbullah di Lebanon, menarik pasukan Suriah dari Lebanon dan tidak lagi ikut campur urusan dalam negeri Lebanon, melakukan liberalisasi politik serta melakukan reformasi politik seperti menghapus undang-undang darurat. ${ }^{28}$

4. Arab Saudi yang telah melakukan banyak kegiatan dibalik layar untuk menggulingkan pemerintah Suriah. Arab Saudi memberi bantuan 100 juta US dolar kepada FSA untuk kegiatan oposisi dan senjata. Selain itu di Arab Saudi juga diadakan penggalangan dana untuk membantu perlawanan di Suriah. Kampanye ini dilakukan oleh Syeikh Al Arifi dengan tujuan mengumpulkan bantuan dari seluruh aktivis dan masyarakat

28 Adeodatus Primus Relod Kota Sera Lumba. (2014). "Intervensi Militer Amerika Serikat Dalam Konflik Politik di Suriah Tahun 2011”. eJournal ilmu Hubungan Internasional. Vol III no. 2, 781. 
Arab Saudi. Kemudian Arab Saudi bersama Arab League mencoba mengangkat isu kekerasan oleh pemerintah Suriah ke PBB, dan meminta pihak internasional untuk terlibat dalam mengatasi Suriah. Akan tetapi pada 4 Februasi 2014, PBB menolak resolusi yang ditawarkan Arab League, yaitu proposal terkait perlunya intervensi pihak internasional. ${ }^{29}$ Meski pada level regional Arab Saudi berhasil menekan Suriah, tetapi tidak pada level internasional. Arab Saudi memiliki kapabilitas dan pengaruh yang cukup besar di Timur Tengah tetapi tidak dalam upaya internasional. Selain itu veto Rusia dan China menjadikan penghambat Arab Saudi untuk mengedepankan politiknya.

\section{F. IMPLIKASI DARI KONFLIK DI SURIAH}

Selanjutnya dampakdariperang Suriah menurutObservatorium Suriah untuk Hak Asasi Manusia, sebuah kelompok pemantau yang berbasis di Inggris, melaporkan pada bulan Desember 2016 bahwa mereka telah mendokumentasikan kematian lebih dari 346.600 orang, termasuk 103.000 warga sipil. Namun tercatat bahwa angka tersebut tidak termasuk 56.900 orang yang hilang dan diduga meninggal dunia. Pada bulan Februari 2017, sebuah kelompok pemikir memperkirakan bahwa konflik tersebut telah menyebabkan 470.000 kematian, baik secara langsung maupun tidak langsung. Menurut badan pengungsi PBB (UNHCR) bahwa hampir 5,5 juta orang, kebanyakan wanita dan anak-anak, telah meninggalkan Suriah. Negara tetangga Suriah, yakni Libanon, Yordania dan Turki telah berjuang untuk mengatasi salah satu eksodus pengungsi terbesar dalam sejarah baru-baru ini. Sekitar 10 persen pengungsi Suriah telah mencari suaka di Eropa, menabur perpecahan politik karena negara-negara saling berdebat untuk berbagi beban. Sebanyak 6,5 juta orang lainnya mengungsi dari dalam Suriah. PBB memperkirakan akan membutuhkan 3,5 milyar dollar untuk membantu 13,1 juta orang yang memerlukan bantuan kemanusiaan di Suriah pada tahun 2018. Hampir 70 persen

29 Fadhly Ikhsan. (2015). "Kebijakan Politik Luar Negeri Arab Saudi Terhadap Krisis Syria (2011-2014). Jom FISIP, Vol II No 2, 9-10. 
penduduk hidup dalam kemiskinan ekstrim. Enam juta orang menghadapi kerawanan pangan akut di tengah kemiskinan dan kenaikan harga. Di beberapa daerah, orang menghabiskan 15-20 persen pendapatan mereka untuk mendapatkan akses terhadap air minum. Partai-partai yang bertikai telah menambah masalah dengan menolak akses agen kemanusiaan kepada banyak orang yang membutuhkan. Sekitar 2,98 juta orang tinggal di daerah yang terkepung atau sulit dijangkau. ${ }^{30}$

Konflik Suriah juga mengakibatkan kota-kota bersejarah menjadi hancur. Aleppo yang merupakan salah satu kota bersejarah terbesar Suriah telah hancur, kompleks Masjid Umayyah yang kuno dan sangat terkenal telah dihancurkan. Hampir semua tempat Warisan Dunia Suriah versi Badan Pelestarian Budaya PBB (UNESCO) telah rusak. Termasuk di kota sebelah utara Aleppo, kota kuno Bosra di selatan, salah satu istana abad pertengahan yang paling penting dilestarikan di dunia Crac des Chevaliers serta situs arkeologi Palmyra. ${ }^{31}$

\section{G. PENYELESAIAN MASALAH KONFLIK DI SURIAH}

Selanjutnya hal yang harus dilakukan untuk mengakhiri konflik, menurut masyarakat internasional bahwa hanya solusi politik yang bisa mengakhiri konflik. Dewan Keamanan PBB telah menyerukan pelaksanaan Komunike Jenewa 2012, yang memberi ide pembentukan sebuah badan pemerintahan transisi dengan kekuatan eksekutif penuh "dibentuk atas dasar kesepakatan bersama”. Perundingan perdamaian yang diperantarai PBB, yang dikenal sebagai proses Jenewa II, dimulai pada awal tahun 2014. Sembilan putaran telah berlangsung, yang terbaru pada bulan Januari 2018. Delegasi diminta untuk membahas reformasi konstitusional dan menyelenggarakan pemilihan yang bebas dan adil. Namun, sedikit kemajuan telah dicapai. Presiden Assad telah

30 https://www.matamatapolitik.com/seluk-beluk-awal-mula-perang-sipil-suriah/ (diakses pada 2 November 2018).

31 Rr Laeny Sulistyawati (2016). Lima Dampak Memilukan Enam Tahun Perang Suriah. http://m.republika.co.id/berita/internasional/timur-tengah/16/03/16/o43r7j377-lima -dampak -memilukan enam -tahun -perang-suriah- part1 (diakses pada 2 November 2018). 
tampak semakin tidak bersedia untuk bernegosiasi dengan oposisi, yang meski menghadapi kekalahan berulang di medan perang yang masih menegaskan bahwa dia harus turun sebagai bagian dari penyelesaian apapun. Dan Utusan Khusus PBB Urusan Suriah Staffan de Mistura mengatakan ia tidak mengharapkan terobosan dalam perundingan, tetapi menambahkan bahwa peluang kali ini lebih besar dari yang sudah-sudah bagi tercapainya kemajuan ke arah berakhirnya perang, yang disebutnya sebagai konflik paling rumit dalam generasi sekarang ini. ${ }^{32}$

Kekuatan Barat mengatakan bahwa Rusia juga berusaha melemahkan perundingan dan memastikan kelangsungan hidup sekutunya (Assad) dengan membentuk sebuah proses politik paralel. ${ }^{33}$ Pada bulan Januari, sebuah "Kongres Dialog Nasional" diadakan di resor Sochi Laut Hitam Rusia. Tapi perwakilan dari kelompok oposisi dan politik oposisi menolak hadir. Konferensi tersebut merupakan hasil pembicaraan antara Rusia, Iran dan Turki yang diadakan di Astana. Kekuasaan tersebut juga disepakati pada bulan Mei 2017 untuk menetapkan empat "zona de-eskalasi" yang mencakup wilayah-wilayah pemberontak utama. Terjadi penurunan pertumpahan darah pada awalnya, namun pada akhir 2017, pemerintah mulai menyerang dua zona tersebut.

\section{H. KESIMPULAN}

Islam merupakan agama kasih sayang dan kesejahteraan, namun dalam praktiknya banyak negara Islam atau negara yang

32 https://www.voaindonesia.com/a/ perundingan- konflik- suriah- dibuka-/3937001.html (diakses pada 2 November 2018).

33 Sejak era perang dingin, Suriah terkenal dengan kekuatan militernya di kawasan, dan identik dengan julukan Rusia Timur Tengah. Hal itu berkat kedekatan hubungan Suriah dengan Rusia, sehingga kerap mendapat suplai senjata modern dari negara digdaya itu. Alasan ini jualah yang membuat Israel sedikit segan untuk melakukan perang frontal menghadapi Suriah dalam persengketaan Dataran Tinggi Golan. Di samping itu, Suriah menjadi tumpuan beberapa negara kawasan dalam menyelesaikan konflik militer yang sering terjadi di Timur Tengah. Fakta membuktikan, bahwa sebagian besar negara Arab adalah aliansi abadi blok Barat, yang dinakhodai langsung oleh Amerika Serikat sebagai kekuatan Super Power tunggal dunia. Keberadaan kekuatan militer Suriah di kawasan tentu saja menjadikan mereka jengah, karena dianggap sebagai kekuatan lawan. Tidak jarang, beberapa kasus sebelumnya sudah pernah diangkat untuk merontokkan Suriah terutama presidennya, namun semuanya gagal. https://www.kompasiana.com /coffeeaceh /550de202813311 b92cbc6013/miris-mengapa-arab-ramai-ramai-memusuhi-suriah (diakses pada 4 November 2018). 
mayoritas penduduknya muslim tidak mengimplementasikan nilai kedamaian itu. Fakta yang yang terjadi di Timur Tengah, sejak musim The Arab Spring, seperti di Negeri-negari Tunisia, Sudan, Libya, Mesir, Irak dan khususnya Suriah di mana mereka berperang antara sesama anak-bangsa. Situasi dan kondisi memunculkan keburaman tentang masa depan mereka. Dan meletusnya The Syiria Spring menjadi puncak ketidakpuasan rakyat Suriah atas Pemerintahan yang berkuasa. Berawal dari demonstrasi kecilkecilan, sekarang Suriah menjadi medan pertempuran oleh berbagai kalangan. Suriah menjadi negara yang mengerikan di mana korban berjatuhan mencapai ratusan ribu jiwa.

Penyebab konflik yang terjadi di Suriah disebabkan oleh beberapa hal diantaranya, (a) Kesenjangan ekonomi, hal ini terjadi di Suriah sejak Hafez Al-Assad memang selalu mengalami fluktuasi. Suriah mengalami penurunan produksi minyak, lapangan pekerjaan yang kurang memadai dan faktor cuaca yang semakin panas membuat lahan pertanian mengalami penurunan. (b) Kebijakan militer Suriah, pada masa Hafez Al-Assad kebijakan pemerintah lebih mengarah ke militer. Dan (c) isu sekterian SunniSyiah yang terus berhembus. Dan faktor kepentingan keterlibatan negara asing, seperti Amerika Serikat, Rusia, Iran dan Arab Saudi menambah daftar panjang konflik yang terjadi di Suriah.

Mengenai tesis Samuel P. Huntington, salah seorang pakar politik dan ahli kajian strategis Amerika Serikat, yang diungkap secara jelas olehnya dalam bukunya The Clash of Civillizations (benturan peradaban) bahwa ia mengatakan setelah ambruknya Uni Soviet, komunisme sekarang ini tidak lagi merupakan ancaman terhadap Barat. Menurut dia bahwa ancaman baru terhadap Barat adalah Islam (dan koalisi antara Islam dan Konfusianisme), adalah tidak benar karena kita bisa melihat dan mengatakan secara pasti bahwa Islam di Arab Saudi sama sekali tidak merupakan momok dan ancaman terhadap Barat. Justeru Barat dalam hal ini Amerika Serikat selalu bermesra-mesraan dengan Arab Saudi karena Amerika Serikat mempunyai kepentingan ekonomi (pasokan minyak) dari Arab Saudi dan juga Arab Saudi sebagai lahan empuk 
pemasaran produk-produk Amerika Serikat. Dengan demikian, lebih tepat apabila Huntington tidak menggeneralisasi Islam atau umat Islam. Sepatutnya ia membatasi pernyataannya itu -jika adapada kelompok-kelompok fundamentalis Muslim yang ada di Iran, Pakistan, Suriah atau negeri-negeri Muslim lainnya. Wallahu 'alamu bisshowab.[] 


\section{DAFTAR PUSTAKA}

ABM, M. Agastya. Arab Spring: Badai Revolusi Timur Tengah. Jogjakarta: IRCiSoD, 2013.

Ahmed, Akbar S. Membedah Islam. Diterjemahkan oleh Zulfahmi Andri. Bandung: Penerbit Pustaka, 1997.

Amiruddin, M. Hasbi. Konsep Negara Islam menurut Fazlur Rahman. Yogyakarta: UII Press, 2000.

Amman (2012). Dua Ribu Tentara Syiria Membelot ke Jordania. m.jpnn.com/news.php?id=140870.

Arkoun, Mohammade, dkk. Serial Dialog Pencerahan Afkar; Orientalisme vis avis Oksidetalisme. Jakarta: Pustaka Firdaus, 2008.

Donohue, John J dan John L Esposito. Islam in Transition: Muslim Perspective. New York: Oxford University, 1982.

http://m.voa-Islam-.com/news/Islamic-world/2011/10/24/16480. http://www.biography.com/people/bashar-as-assad-20878575.

https:/ilmupengetahuanumum.com/profil-negara-suriah-syria/ https://republika.co.id/berita/kolom/resonansi/18/08/09/ pd64jd440-agama-sebagai-realitas-historis-1.

https://www.dw.com/id/militer-israel-dan-iran-saling-serang-diwilayah-suriah/a-43728413.

https://www.kompasiana.com /coffeeaceh /550de202813311 b92cbc6013/miris-mengapa-arab-ramai-ramaimemusuhi-suriah.

https://www.matamatapolitik.com/seluk-beluk-awal-mulaperang-sipil-suriah/.

https://www.merdeka.com/dunia/kilas-balik-akar-penyebabkonflik-suriah-setelah-lima-tahun.html.

https://www.republika.co.id/berita/pendidikan/dunia- 
kampus/14/03/17/n2k7oj-azyumardi-dikotomi-baratdan-timur-harus-dipersempit.

https://www.voaindonesia.com/a/perundingan-konflik-suriahdibuka-/3937001.html.

Huntington, Samuel P. Benturan Antar Peradaban, dan Masa Depan Politik Dunia. Diterjemahkan oleh M. Sadat Ismail. Yogyakarta: Qalam, 2000.

Ikhsan, Fadhly. (2015). "Kebijakan Politik Luar Negeri Arab Saudi Terhadap Krisis Syria (2011-2014). Jom FISIP, Vol II No 2.

Ismail, Faisal. Ketegangan Kreatif Peradaban Islam; Idealisme versus Realisme. Jakarta: PT. Bakti Aksara Persada, 2003.

Jainuri, Achmad. Orientasi Ideologi Gerakan Islam: Konservatisme, Fundamentalisme, Sekularime, dan Modernisme. Surabaya: LPAM, 2004.

Kuncahyono, Trias. Musim Semi di Suriah: Anak-anak Penyulut Revolusi. Jakarta: Kompas, 2012.

Lumba, Adeodatus Primus Relod Kota Sera. (2014). “Intervensi Militer Amerika Serikat Dalam Konflik Politik di Suriah Tahun 2011”. eJournal ilmu Hubungan Internasional. Vol III no. 2.

Robinson, Neal. Pengantar Islam Komprehensif. Diterjemahkan oleh Anam Sutopo, dkk. Jakarta: PT. Bakti Aksara Persada, 2003.

Shaoul, Jean and Chris Marsden. (2000). The Bitter legacy of Syria's Hafez Al-Assad. https://www.wsws.org/en/ articles/2000/06/assa-j16.html.

Sihbudi, M. Riza. Islam, Dunia Arab, Iran: Bara Timur Tengah. Mizan: Bandung, 1991.

Suarapembaharuan.com. (2016). Rusia Tak Mau Suriah Hancur Seperti Libia. http://sp.beritasatu.com/home/rusia-takmau-suriah-hancur-seperti-libia/14241. 
Sulistyawati, Rr Laeny (2016). Lima Dampak Memilukan Enam Tahun Perang Suriah. http://m.republika.co.id/berita/ internasional/timur-tengah/16/03/16/o43r7j377-limadampak-memilukanenam-tahun-perang-suriah-part1.

Turner, Bryan S.. Runtuhnya Universalitas Sosiologi Barat Wacana atas; Islam vis a vis Barat, Orientalisme, Postmodernisme dan Globalisme. terj. Sirojuddin Arif, dkk. Yogyakarta: Ar-Ruzz Media, 2008. 